SJ Quinney College of Law, University of Utah

Utah Law Digital Commons

2-5-2021

Using Current Legal Tools to Achieve Net Zero Greenhouse Gas Emissions from New and Existing Federal Oil and Gas Leases

Jamie Gibbs Pleune

Nada Wolff Culver

John C. Ruple

Follow this and additional works at: https://dc.law.utah.edu/scholarship

Part of the Environmental Law Commons, Land Use Law Commons, and the Natural Resources Law Commons 


\section{Using Current Legal Tools to Achieve Net Zero Greenhouse Gas Emissions from New and Existing Federal Oil and Gas Leases.}

February 5, 2021

Jamie Gibbs Pleune

Nada Wolff Culver

John C. Ruple

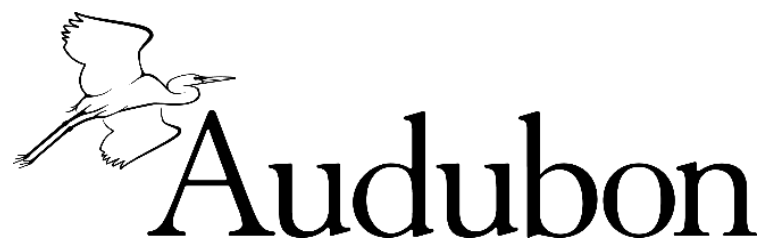


Fossil fuel development on federal lands accounts for $24 \%$ of all U.S. carbon dioxide $\left(\mathrm{CO}_{2}\right)$ emissions. ${ }^{1}$ These emissions can be reduced significantly by requiring federal oil and gas development activity to mitigate greenhouse gas (GHG) emissions. ${ }^{2}$

The Bureau of Land Management (BLM) has authority to define the terms and conditions of new oil and gas leases and to impose conditions of approval on existing leases at the drilling stage. Using this authority, the BLM could require net zero emissions on some existing and all new oil and gas leases without waiting for congressional action or regulatory changes.

This approach would allow for continued production while a long-term climate strategy is developed and still drive significant GHG emission reductions in the meantime. Additionally, green jobs would be created by incentivizing oil and gas operators to generate offset credits by plugging the more than 2 million orphaned or abandoned oil and gas wells that litter the landscape. Finally, the incentive to plug idle wells and retire leases early would reward operators for deciding to keep some fossil fuel resources in the ground.

\section{The BLM has the legal authority to impose a net zero requirement on existing leases that have not been drilled yet.}

Oil and gas development occurs in three phases. First, the BLM determines which lands are available for leasing when it prepares landscape scale Resource Management Plans. These plans "shall" be amended when new information becomes available or when circumstances change. ${ }^{3}$ Second, prior to a lease sale, the BLM analyzes individual leases and may use this information to impose stipulations that protect other resources managed by the BLM. Third, before approving an Application to Drill (APD), the BLM conducts a final analysis and imposes conditions of approval as necessary to mitigate harm to other resources.

There are 38,294 existing federal oil and gas leases, but only 24,127 of them are producing oil or gas. ${ }^{4}$ That means that there are potentially 14,167 leases (covering over 13.3 million acres) that have been sold, but not yet drilled. On January 27, 2021, President Biden signed an Order to "pause new oil and natural gas leases on public lands" in order to reconsider leasing practices in light of "potential climate and other impacts associated with oil and gas activities." Addressing the potential GHG emissions arising from these existing leases is critical to achieving net-zero emissions on federal lands.

The BLM has authority to impose a net-zero requirement on existing leases when the operator applies to drill a well. The BLM retains extensive contractual and regulatory authority to impose mitigation measures as a condition of approval at the APD stage. ${ }^{6}$ The BLM has used this authority to incorporate mitigation measures into drilling plans, even if those requirements were not identified at the time of the lease sale. ${ }^{7}$ Both the BLM and industry have justified expedited environmental analyses at the leasing stage by promising to mitigate impacts at the APD stage. ${ }^{8}$ Thus, operators already expect that mitigation measures will be imposed at the APD stage. A net zero requirement is an appropriate way to minimize adverse impacts to land, air, water, cultural, and biological resources, and other users, as required by the Standard Lease Terms.

The BLM recently affirmed its authority to impose GHG mitigation measures at the APD stage. In WildEarth Guardians v. Zinke, the federal district court for the District of Columbia remanded the BLM's sale of 283 parcels because the "BLM failed to take a 'hard look' at GHG emissions." The BLM then prepared an Environmental Assessment, promising to mitigate GHG emissions at the APD stage through conditions of approval and best management practices (in 
addition to applicant committed measures and state air quality permits). ${ }^{10}$ Other BLM field offices already impose GHG mitigation through Best Management Practices or Conditions of Approval at the APD stage, further demonstrating the BLM's existing authority. For example, the Colorado BLM State Office strategy for reducing emissions from oil and gas development through best management practices includes GHG emission control measures. ${ }^{11}$

\section{The BLM also has the authority to impose a net zero requirement on all new leases through two additional mechanisms.}

Before leasing ever occurs, the BLM can revise land use plans to impose a net zero emissions stipulation on all new oil and gas activity. Recent data regarding climate change constitutes a change in circumstances that justifies revising land use plans. Failure to mitigate GHG emissions from oil and gas development activity will exacerbate climate change, resulting in permanent impairment of atmospheric resources and unnecessary or undue degradation of the lands. Both of these results would be contrary to the BLM's management mandate. ${ }^{12}$

Even if the BLM does not update an existing RMP, the site-specific environmental analysis required at the leasing stage provides an opportunity to assess whether the assumptions supporting the RMP decision remain valid, and whether adaptive management strategies require that mitigation measures be imposed. ${ }^{13}$ Because the lease is a contract, the BLM has broad authority to define the terms of the contract prior to sale, and stipulations have been used in a wide variety of contexts to adjust lease terms to avoid adverse effects related to energy development. ${ }^{14}$ Exacerbating climate change is an adverse effect of energy development and GHG mitigation should be incorporated into the terms of the lease to create predictability for future development.

\section{Imposing a net zero mitigation requirement would be consistent with the BLM's existing statutory, regulatory, and contractual mitigation authority.}

Three statutes and their implementing regulations provide authority for the BLM to impose GHG mitigation requirements during the oil and gas permitting process in order to protect other resources consistent with the BLM's multiple use mandate.

The Federal Land Policy and Management Act (FLPMA) ${ }^{15}$ directs the BLM to balance multiple uses and avoid permanent impairment of resources, including atmospheric values. ${ }^{16}$ It also imposes a mandatory duty to prevent unnecessary or undue degradation. ${ }^{17} \mathrm{GHG}$ emissions from fossil fuel development on public lands accounts for $24 \%$ of U.S. emissions, and continued development will result in permanent impairment and unnecessary or undue degradation of the lands. ${ }^{18}$ Since at least 2008, the BLM has recognized that its authority to identify and implement mitigation measures (both onsite and offsite of mineral development leases) arises out of FLPMA and the authority to regulate public land uses. ${ }^{19}$

Regulations under the Mineral Leasing Act require that "all operations" be conducted in a manner that "protects other natural resources and the environmental quality." 20 Supporting regulations specify that operators must conduct all operations in a manner that protects "other natural resources and environmental quality." 21 Mitigating GHG emissions will protect other natural resources and environmental quality.

The National Environmental Policy (NEPA) and the Department of Interior's implementing regulations impose procedural requirements to consider alternatives, including mitigation. ${ }^{22}$ These requirements are unaffected by recent changes to the CEQ's NEPA regulations. ${ }^{23}$ 
The BLM utilizes a Standard Lease Form to solemnize the contract it enters into with oil and gas operators. Plain language of the Standard Lease Form puts every lessee on notice that the right to drill for oil and gas on federal land is subject to the duty to minimize adverse impacts, even if those impacts are not contemplated at the time of the lease sale. Additionally, operations may be restricted for environmental reasons. ${ }^{24}$ The plain language of the standard lease form notifies each lessee that the BLM reserves contractual authority to impose additional mitigation and reclamation measures after the lease is signed and when the lessee applies to drill.

\section{Existing disclosure procedures can be used to calculate GHG offset requirements.}

The existing regulatory and legal structure already requires oil and gas operators to disclose GHG emissions associated with new drilling activity. ${ }^{25}$ Most permitting processes include a Reasonably Foreseeable Development Scenario setting forth estimated well or mine production, which can be used to anticipate downstream emissions. ${ }^{26}$ This "serves as a baseline" in the NEPA analysis, ${ }^{27}$ and could be used to anticipate offset requirements. That baseline could be compared against actual production to ensure that the offset estimate was accurate.

\section{Standards for offset validation and verification exist and can be used to set the net zero mitigation requirement.}

A robust international market for voluntary carbon reductions and offsets already exists and is used widely. ${ }^{28}$ The carbon offset industry has developed voluntary standards for proper accounting, transparency, and certification. ${ }^{29}$ Those standards ensure that carbon credits are real, measurable, permanent, not already required by law, independently verified, unique, and contribute to sustainable development. The infrastructure created by the existing voluntary carbon market can be used to validate and verify the net-zero offset requirement without imposing a new regulatory burden on the BLM.

Using a well-established technical standard developed voluntarily by industry is consistent with long-standing federal law and guidance. Guidance issued by the Office of Management and Budget and in effect since the 1980s directs federal agencies, where practicable, to utilize privately developed standards rather than writing new, government-unique standards. ${ }^{30}$ Section $12(\mathrm{~d})$ of the National Technology Transfer and Advancement Act of 1995 also directs that unless inconsistent with law or impractical, all federal agencies should use "technical standards that are developed or adopted by voluntary consensus standards bodies . . . to carry out [the agencies'] policy objectives or activities." 31

\section{Operators could achieve offset credits by retiring leases early, plugging idle wells, or by plugging orphaned or abandoned wells.}

Emissions avoidance is an important strategy for achieving net zero emissions. Operators could create offset credits by retiring leases early and choosing to leave some resources in the ground. ${ }^{32}$

Idle wells emit significant methane emissions without benefitting society. ${ }^{33}$ In 2019 , the Government Accountability Office identified 2,294 idle wells that have not produced oil or gas since June 2008. ${ }^{34}$ With industry forecasts predicting that prices will remain below 2008 levels for at least thirty more years, it is unlikely that these wells will be brought back into production, which means that they will continue to emit and that they face an increased risk of becoming orphaned

or abandoned. ${ }^{35}$ Operators could achieve offset credits by plugging idle wells early to avoid unnecessary and harmful GHG emissions. 
Orphaned and abandoned wells also present a problem. The EPA estimates that the population of unplugged abandoned oil and gas wells was around 2.1 million in 2018. ${ }^{36}$ These orphans have steadily produced between 6 and 7 million metric tons (MMT) of $\mathrm{CO}_{2}$ equivalent annually between 1990 and the present, primarily through methane emissions. ${ }^{37}$ Operators could achieve offset credits by plugging orphaned and abandoned wells for which they have no existing legal responsibility to remediate.

The American Carbon Registry has already approved a methodology for offset protocols for methane capture projects including coal mines. ${ }^{38}$ A clear methodology is important due to variability in the amounts of GHG emissions released by different wells. ${ }^{39}$ Currently, the American Carbon Registry is in the process of developing a methodology that will standardize the way abandoned well projects can participate in the offsetting registry. ${ }^{40}$

\section{Imposing a net-zero requirement on new oil and gas development would contribute to green jobs by putting oil field workers to work.}

After a downturn in oil and gas prices in 2014, the number of idle and orphaned wells increased beyond the ability of existing policy measures to identify, manage, and clean-up those wells. ${ }^{41}$ The same dynamic is unfolding today, further exacerbating the problem. Oil and gas bankruptcies in the United States and Canada rose 50\% in 2019, and analysts say the rate is likely to accelerate with the pandemic-related slide in energy prices. ${ }^{42}$ That will increase the number of abandoned wells and decrease the operators available to plug them.

Companies that declare bankruptcy or shutter operations have few resources to plug idle wells, and bonding requirements rarely cover the cost of plugging these wells. A recent Government Accountability Office (GAO) report found a vast discrepancy between the cost of plugging a well and the financial bond posted by operators, which creates an incentive for operators to abandon wells instead of reclaiming them. ${ }^{43}$ Bond minimums do not reflect the characteristics of individual wells, such as depth or location, even though those characteristics affect the cost. ${ }^{44}$ Even though the complexity of drilling and the cost of plugging wells has increased, the minimum bond requirements have remained unchanged since the $1960 \mathrm{~s} .{ }^{45}$ The average cost of plugging a well ranges from $\$ 20,000$ in a low-cost scenario to $\$ 145,000$ in a high-cost scenario. ${ }^{46}$ Considering only the 2,294 wells that have not produced since 2008, the GAO estimated that the cost of reclamation could range from $\$ 46$ million in a low-cost scenario to $\$ 333$ million in a high cost scenario. An offsetting program would incentivize solvent operators to help resolve this otherwise unmanageable problem.

Some oil and gas industry workers have already sought ways to pivot their skills from drilling oil and gas wells to plugging them. ${ }^{47}$ Offsetting requirements would support these potential green jobs. Offsetting requirements could also supplement proposals to remediate wells through stimulus packages. For example, the House of Representatives included funding to plug abandoned wells using laid-off oil and gas workers in the July infrastructure bill. ${ }^{48}$

In summary, achieving net-zero emissions on federal lands will require quick and creative action. Using its existing contractual and regulatory authority, the BLM can impose a net-zero requirement on all new wells and all new leases. This approach would provide certainty to industry, create green jobs, and help resolve a looming crisis of orphaned and abandoned wells. 
Jamie Gibbs Pleune is a Wallace Stegner Center Legal Fellow, S.J. Quinney College of Law at the University of Utah.

Nada Wolff Culver is Vice President, Public Lands and Senior Policy Counsel, at the National Audubon Society.

\author{
John C. Ruple is Professor of Law (research) and Wallace Stegner Center Legal Fellow, S.J. \\ Quinney College of Law.
}

\footnotetext{
${ }^{1}$ U.S. Geological Survey, Federal Lands Greenhouse Gas Emissions and Sequestration in the United States: Estimates for 2005-14, 1 (2018). Federal lands are also significant contributors of methane $\left(\mathrm{CH}_{4}\right)$ and nitrous oxides $\left(\mathrm{N}_{2} \mathrm{O}\right)$, both of which are also powerful greenhouse gasses. Id.

2 The ideas set forth in this policy paper are thoroughly explored in the following two articles: Jamie Gibbs Pleune, John C. Ruple, Nada Wolff Culver, The BLM's Duty to Incorporate Climate Science into Permitting Practices and a Proposal for Implementing a Net Zero Requirement into Oil and Gas Permitting, 32 Colo. Nat. Res. Energy \& Envtl. L. Rev. (2021) (available at https://papers.ssrn.com/sol3/papers.cfm?abstract id=3756375) [hereinafter Pleune et al., BLM's Duty to Incorporate Climate Science into Permitting]; and Jamie Gibbs Pleune, John C. Ruple, Nada Wolff Culver, A Roadmap to Net-Zero Emissions for Fossil Fuel Development on Public Lands, 50 Environmental Law Reporter 10734 (Sept. 2020) (available at https://www.eli.org/sites/default/files/docs/elr_pdf/50.10734.pdf) [hereinafter Pleune et al., A Roadmap to NetZero].

343 C.F.R. § 1610.5-5 (2019).

${ }^{4}$ Bureau of Land Management, Oil and Gas Statistics, https://www.blm.gov/programs/energy-and-minerals/oil-andgas/oil-and-gas-statistics (last visited Feb. 4, 2021) (Figures quoted were obtained with data from tables 1, 2, 5 and 6 , and reflect information for FY2019). These figures do not include offshore leases or wells.)

${ }^{5}$ Exec. Order 14008, 86 Fed. Reg. 7619, 7624-25 (Jan. 27, 2021).

${ }^{6}$ United States Dep't. of Interior, Form 3100-11, Offer to Lease and Lease for Oil and Gas (October 2008) [hereinafter Form 3100-11]; Yates Petroleum Inc. 176 IBLA 144, 154 (2008) (upholding mitigation measures imposed as COAs that were more stringent than standards in the RMP); BLM Surface Operating Standards and Guidelines for Oil and Gas Exploration and Development: The Gold Book § 2.3 (4th ed. 2007) (noting that constraints on operations may result from a variety of sources including "the surface management agency's review and environmental analysis of the proposed operations").

${ }^{7}$ U.S. Dept. of Interior et al., Inventory of Onshore Federal Oil and Natural Gas Resources and Restrictions to their Development 12 (2008) available at https://www.blm.gov/sites/blm.gov/files/EPCA III Inventory Onshore Federal Oil Gas.pdf [hereinafter DOI, Inventory of Federal Oil and Gas Leases] (surveying all onshore federal leases and identifying post lease restrictions and conditions of approval).

${ }^{8}$ See San Juan Citizens Alliance v. United States Bureau of Land Management, 326 F. Supp. 3d 1227, 1244-46 (D.N.M. 2018) (upholding BLM decision to defer analyzing GHG mitigation measures until the APD stage). See, also Duna Vista Resorts, 187 IBLA 43, 56 (2016) (concluding that it was appropriate to issue a FONSI at the leasing stage because the BLM had authority to mitigate all potential environmental effects by imposing COAs at the APD stage, including dictating which formation the lessee could drill into).

9 368 F. Supp. 3d 41, 85 (D.D.C. 2019).

${ }^{10}$ BLM, Supplemental Environmental Assessment for the May 2015 - August 2016 Sold and Issued Leases DOIBLM-WY-0000-2019-0007-EA 26 (2019) https://bit.ly/2D9ZYQo (last visited Feb. 4, 2021) (arguing that GHG analysis is unnecessary at the leasing stage because "[a]nalysis and approval of future development of the lease parcels may include application of BMPs within BLM's authority, as Conditions of Approval (COAs) to reduce or mitigate GHG emissions.”).

${ }^{11}$ Colorado Bureau of Land Management, Comprehensive Air Resource Protection Protocol (CARPP) 15-20 (July 2015) available at https://www.blm.gov/sites/blm.gov/files/uploads/program_natural\%20resources_soil\%20air\%20water_airco_quick \%20link_CARPP.pdf (last visited Feb. 4, 2021).
} 
${ }^{12}$ See 43 U.S.C. § 1702(c) (2018) (requiring the Secretary of the Interior to prevent "permanent impairment of the productivity of the land and the quality of the environment," and § 1732(b) (requiring the Secretary of the Interior to "take any action necessary to prevent the unnecessary and undue degradation of the lands.").

1343 C.F.R. § 46.145 (2019).

${ }^{14}$ DOI, Inventory of Federal Oil and Gas Leases supra note 7 (surveying 128 Federal land use plans and finding approximately 3,125 individual stipulations in place).

1543 U.S.C. $\$ \S 1701-84(2018)$.

1643 U.S.C. $\S 1702$ (c); id. $\S 1701$ (a)(8). For a thorough discussion of the BLM's statutory duty to address climate change, see Pleune et al., BLM's Duty to Incorporate Climate Science into Permitting supra note 2 at 22-30 and Pleune et al., Roadmap to Net Zero supra note 2 at 10736-38.

1743 U.S.C. $\$ 1732$ (b) (2018).

18 Pleune et al., BLM's Duty to Incorporate Climate Science into Permitting supra note 2 at 21-30; Pleune et al., Roadmap to Net Zero supra note 2 at 10736.

${ }^{19}$ Bureau of Land Mgmt., Offsite Mitigation, Instruction Memorandum No. 2008-204 (Sept. 30, 2008), Attachment $1-1$.

2043 C.F.R. $\$ 3161.2$ (2019).

2143 C.F.R. § 3162.1(a) (2019); 43 C.F.R. § 3162.5-1(a) (2019).

2242 U.S.C. $\S 4332$ (C)(iii) (2018); 43 C.F.R. $\S 46.130$ (a) (2019). See also 85 Fed. Reg. at 43360, to be codified at 40 C.F.R. $\S 1502.14(\mathrm{e})$ (requiring that EISs "[i]nclude appropriate mitigation measures not already included in the proposed action or alternatives.").

${ }^{23}$ For a more thorough discussion of this statement, see Pleune et al., BLM's Duty to Incorporate Climate Science into Permitting supra note 2 at 45-51.

${ }^{24}$ Form 3100-11 supra note 6 at 3, Sec. 6 . These contractual provisions are consistent with the BLM's regulations. 43 C.F.R. $\S \S 3101.1-2$ (2019); id. § 3162.5-1(a).

${ }^{25}$ In addition to the emissions occurring at the exploration and production phases, multiple courts hold that NEPA requires the BLM to also consider the "indirect effect" of downstream emissions resulting from refining and consuming the fuel after it is sold. Pleune et al., supra note 2 BLM's Duty to Incorporate Climate Science into Permitting at 56-58 (collecting cases).

${ }^{26}{ }^{26}$ R Terms, "Reasonably Foreseeable Development Scenario (RFDS), 8 Williams \& Meyers, Oil and Gas Law Scope (2019).

${ }^{27}$ Id. (citing Deborah Reichman, 173 IBLA 149, 157 (2007)).

${ }^{28}$ See, e.g., Stephen Donofrio et al, Voluntary Carbon and the Post-Pandemic Recovery: A Special Climate Week NYC 2020 Installment of Ecosystem Marketplace's State of the Voluntary Carbon Market 2020 Forest Trends' Ecosystem Market Place 2 (Sept. 21, 2020) available at https://share.hsforms.com/1ICNqRm4gSRGccSuyRZFdg1yp8f (last visited Feb. 4, 2021) (reporting that the 2019 market volume topped 1.3 billion tons of $\mathrm{C}_{2} \mathrm{e}$ with a value of $\$ 5.5$ billion dollars).

${ }^{29}$ See, e.g., International Carbon Reduction \& Offset Alliance, ICROA Code of Best Practice: Executive Summary (2020) available at https://www.icroa.org/resources/Documents/ICROA cobp carbon management service executive summary 2020 .$p d f$ (last visited Feb. 4, 2021) (defining international best practice for offset-inclusive carbon management and listing seven recognized standards for validation, verification, and registry: Clean Development Mechanism, Climate Action Reserve, Gold Standard, Joint Implementation, Verified Carbon Standard, American Carbon Registry, Emissions Reduction Fund of the Australian Government).

${ }^{30}$ See Office of Mgmt. \& Budget Circular No. A-119 Revised: Federal Participation in the Development and Use of Voluntary Consensus Standards and in Conformity para. 1 (1998) (directing agencies to rely on voluntary standards, including industry standards or consensus codes, rather than "government-unique standards."); see also Office of Mgmt. \& Budget Circular No. A-119 Revised: Federal Participation in the Development and Use of Voluntary Consensus Standards and in Conformity para. 1 (2016) (reaffirming commitment to use voluntary consensus standards where appropriate or adaptable for federal purposes).

${ }^{31}$ Utilization of Consensus Technical Standards by Federal Agencies; Reports Act, March 7, 1996, P.L. 104-113 § 12(d), 110 Stat. 783; Dec. 28, 2001, P.L. 107-107, Div. A, Title XI, Subtitle B, § 1115, 115 Stat. 1241 (directing that "all Federal agencies and departments shall use technical standards that are developed or adopted by voluntary 
consensus standards bodies, using such technical standards as a means to carry out policy objectives or activities determined by the agencies and departments").

32 See, e.g. Bill McKibben, The Biggest Carbon Challenge: Leave It in the Ground Scientific American (Nov. 30, 2015) available at https://www.scientificamerican.com/article/the-biggest-climate-challenge-leaving-carbon-in-theground/ (last visited Feb. 4, 2021).

${ }^{33}$ Recent studies indicate that emissions from idle wells tend to be higher than estimated emissions from orphaned or abandoned wells. See James P. Williams, Amara Regehr, and Mary Kang, Methane Emissions from Abandoned Oil and Gas Wells in Canada and the United States 55 Environ. Sci. Technol. 563-570 (Dec. 15, 2020); Erick Lebel et al., Methane Emissions from Abandoned Oil and Gas Wells in California, Environ. Sci. Technol. (Oct. 30, 2020).

${ }^{34}$ U.S. Gov't Accountability Off.. GAO-19-615. Oil and Gas: Bureau of Land Management Should Address Risks from Insufficient Bonds to Reclaim Wells 17 (2019) [hereinafter GAO-19-615, Insufficient Bonds to Reclaim Wells]. ${ }^{35} I d$. at 18.

${ }^{36}$ U.S. EPA, Inventory of U.S. Greenhouse Gas Emissions and Sinks 1990-2018, 3-101 (2020) available at https://www.epa.gov/ghgemissions/inventory-us-greenhouse-gas-emissions-and-sinks-1990-2018 (last visited Feb. 4, 2021)

${ }^{37} I d$. at Executive Summary ES-8.

${ }^{38}$ American Carbon Registry, ARB Mine Methane Capture Offset Projects-Listing, Verification and Offset Credit Issuance (June 11, 2014) available at https://americancarbonregistry.org/news-events/events/arb-mmcreprotocol?searchterm=abandon (last visited Feb. 2, 2021).

${ }^{39}$ For example, a study in Pennsylvania found that $15 \%$ of the abandoned and orphaned oil and gas wells accounted for almost all of the state-inventoried emissions from this source. See Kang et al., Identification and Characterization of High Methane-Emitting Abandoned Oil and Gas Wells 113 Proc. Nat. Acad. Sci. 13636 (Nov. 2016) available at https://www.pnas.org/content/113/48/13636.

${ }^{40}$ Emily Pontecorvo, Abandonment Issues Grist (Dec. 1, 2020) available at https://grist.org/energy/pluggingabandoned-oil-wells-carbon-offsets/ (last visited Feb. 2, 2021) [hereinafter Pontecorvo, Abandonment Issues]

${ }^{41}$ Vanessa Alboiu, Tony Robert Walker, Pollution Management and Mitigation of Idle and Orphaned Oil and Gas Wells in Alberta, Canada 191 Environmental Monitoring and Assessment 611 (Sept. 2019).

${ }^{42}$ Nichola Groom, Special Report: Millions of Abandoned Oil Wells are Leaking Methane, a Climate Menace Reuters (June 16, 2020) available at https://www.reuters.com/article/us-usa-drilling-abandonedspecialreport/special-report-millions-of-abandoned-oil-wells-are-leaking-methane-a-climate-menaceidUSKBN23N1NL (last visited Feb. 4, 2021); see also Press Release, Rystad Energy, North American Oil and Gas Bankruptcy Debt Reached an All-Time High in 2020 And Is Set to Grow (Oct. 22, 2020) available at https://www.rystadenergy.com/newsevents/news/press-releases/north-american-oil-and-gas-bankruptcy-debtreached-an-all-time-high-in-2020-and-is-set-togrow/\#: : :text=Under\%20this\%20scenario\%2C\%20associated\%20debt,debt\%20of\%20about\%20\%2444\%20billion (last visited Feb. 4, 2021).

${ }^{43}$ GAO-19-615, Insufficient Bonds to Reclaim Wells supra note 33 at 15.

${ }^{44} \mathrm{Id}$. at 17.

${ }^{45} \mathrm{Id}$. at 16

${ }^{46} I d$. at 6.

${ }^{47}$ Pontecorvo, Abandonment Issues Grist supra note 41.

${ }^{48}$ Silvio Marcacci, Plugging Abandoned Oil Wells is One 'Green New Deal' Aspect Loved by Both Republicans and Democrats, Forbes (Sept. 21, 2020) available at https://www.forbes.com/sites/energyinnovation/2020/09/21/plugging-abandoned-wells-the-green-new-deal-jobsplan-republicans-and-democrats-love/?sh=34bfd39e2e10.

This paper was made possible by the generous support provided by the Wilburforce Foundation. The Wilburforce Foundation did not review any aspect of this Article prior to publication or otherwise exercise editorial control. The views expressed herein do not necessarily represent those of the state of Utah, the University of Utah, or the Wilburforce Foundation. 